\title{
Analisis Fenotip, Pendugaan Bobot Tetas dan Bobot Hidup Umur 8 Minggu pada Seleksi Ayam Kampung (Gallus gallus domesticus)
}

\author{
Phenotype Analysis, Estimation of Hatching Weight and Life Weight at 8 Weeks \\ in Local Chicken (Gallus domesticus) Selections
}

Yusnaini B. Talebe*, Abdurahman Hoda, Sri Utami

Program Studi Peternakan Fakultas Pertanian Universitas Khairun

*Korespondonsi Email: yusnaini@unkhair.ac.id

Diterima 28 Februari 2020; Disetujui 18 Juni 2021

\begin{abstract}
ABSTRAK
Kota Ternate memiliki variasi ayam kampung tinggi dan khas, dari karakter fenotip yang ada. Hingga sekarang belum ada kajian yang dapat mengidentifikasi jumlah rumpun ayam lokal asli yang beranekaragam tersebut. Penyediaan bibit ayam lokal dengan mutu genetik yang baik sangat sulit diperoleh, karena belum ada bibit ayam lokal hasil pemuliaan dari rumpun dengan struktur breeding yang jelas. Melihat permasalahan ini maka perlu dilakukan penelitian dengan tujuan membentuk rumpun baru ternak ayam lokal khas Kota Ternate. Peneltian ini menggunakan metode eksperimental design dengan tahapan sebagai berikut: Tahap awal: Penelitian dilakukan perkawinan antara ayam kampung jantan berjumlah 5 ekor dengan betina berjumlah 25 ekor. Tahap kedua : Hasil pengumpulan telur selama seminggu dimasukkan ke dalam mesin penetasan. Setelah telur menetas anak ayam umur sehari diberi wing band sebagai identitas lalu dilakukan penimbangan untuk memperoleh data bobot tetas. Tahap ketiga: Anak ayam kampung yang telah diberi wing band dimasukkan ke kandang kelompok dari ram kawat berukuran $70 \times 60 \times 30 \mathrm{~cm}$ dilengkapi induk buatan. Pemberian ransum dan air minum diberikan 2 kali sehari, pagi dan sore. Penimbangan bobot hidup pada tiap individu dilakukan setiap minggu sampai dengan umur 8 minggu. Peubah yang diamati adalah selain karakter fenotip, juga bobot telur, bobot tetas dan bobot, kemudian analisis data digunakan untuk melihat keragaman pada masing-masing parameter. Hasil penelitian menunjukkan bahwa tingkat keragaman baik karakter fenotip maupun tingkat produktivitas ayam buras masih dalam kategori tinggi, maka upaya seleksi perlu dilakukan secara kontinyu untuk memperoleh strain ayam buras murni.
\end{abstract}

Kata kunci: Fenotipe, Bobot Tetas, Bobot Hidup, Ayam Kampung

\begin{abstract}
Research with the title phenotypic analysis, estimation of hatching weight and 8 week life weight in the selection of native chickens (Gallus domesticus) was conducted in Ternate City. Ternate has a variety of high and distinctive native chickens, from the existing phenotypic characters. Until now there has been no study that can identify the number of diverse native local chicken clumps. Provision of local chicken seeds with good genetic quality is very difficult to obtain, because there are no local chicken breeds resulting from breeding from clumps with a clear breeding structure. Seeing this problem, it is necessary to
\end{abstract}


conduct research with the aim of forming new clumps of local chicken livestock typical of Ternate City. This research used an experimental design method with the following stages: Initial stage: The study was carried out by marriages between 5 male native chickens and 25 females. The second stage: The results of collecting eggs for a week are put into the hatchery. After the eggs hatch, the DOC is given Wing band as an identity, then weighing it to obtain hatching weight data. The third stage: Village chicks that have been given wing bands are put into the group cage made of wire ram measuring $70 \times 60 \times 30 \mathrm{~cm}$ equipped with artificial broodstock. Rations and drinking water were given 2 times a day, morning and evening. Weighing the live weight of each individual is carried out every week until the age of 8 weeks. The parameters observed were in addition to the phenotypic character, as well as egg weight, hatching weight and weight, then data analysis was used to see the diversity in each parameter. The results showed that the diversity level of both the phenotypic characters and the productivity level of native chickens was still in the high category, so selection efforts needed to be carried out continuously to obtain pure native chicken strains.

Keywords: Phenotype, Hatching Weight, Live Weight, Native Chickens

\section{PENDAHULUAN}

Ayam kampung merupakan sebagian dari rumpun-rumpun ayam lokal yang kita miliki dengan potensi besar untuk dikembangkan menjadi bibit unggul dalam upaya menunjang ketahanan pangan dan meningkatkan kesejahteraan petani. Indonesia dilaporkan terdapat 32 jenis ayam lokal (ecotype) dan masing-masing jenis memiliki keunggulan tersendiri, seperti ayam pelung, sentul, kedu, merawang, gaok, dan nusa penida (Sartika, 2012).

Upaya peningkatan kualitas dan kuantitas rumpun ayam lokal dapat dilaksanakan dengan pemurnian dan persilangan rumpun-rumpun ayam lokal. Pemurnian rumpun ayam lokal bertujuan untuk melestarikan, memanfaatkan dan mengembangkan sumberdaya genetik (SDG) ayam lokal.

Food Agiculture Organisation (FAO) telah memberikan batasan SDG hewan (termasuk ternak) adalah jenis hewan yang digunakan atau dapat digunakan, untuk produksi pangan dan pertanian, serta setiap jenis dalam populasi tertentu termasuk populasi liar, rumpun asli dan lokal yang telah ditetapkan atau belum terseleksi berdasarkan genetik, strain, breed dan materi genetik yang telah dilestarikan serta semua materi genetik lainnya yang diakui saat ini (BISE, 2010; Hiemstra et al., 2011; FAO 2012).

Saat ini, penyediaan bibit ayam lokal dengan mutu genetik yang baik sangat sulit diperoleh, karena belum ada bibit ayam lokal hasil pemuliaan dari rumpun dengan struktur breeding yang jelas. Kebanyakan penyediaan bibit ayam lokal yang ada, baru terbatas pada 
usaha-usaha penetasan untuk keperluan peternak sendiri atau untuk dijual berdasarkan pemesanan terlebih dahulu. Kualitas bibit dalam hal ini tidak didasarkan pada kriteria kualitas tertentu. Bibit yang dipilih berkualitas apa adanya. Bahkan banyak sekali yang berasal dari hasil persilangan dengan ayam ras atau dengan ayam Bangkok atau ayam Arab. Penyediaan bibit hasil silangan seperti disebutkan di atas telah berkembang khususnya di daerah Jawa.

Namun demikian perhatian dan pemanfaatan rumpun ayam lokal yang kita punyai masih sangat rendah. Hal tersebut dikarenakan produksi telur dan daging ayam lokal yang diusahakan peternak, relatif rendah. Penyebab utama rendahnya produktifitas ini adalah mutu bibit yang rendah dengan adanya sifat mengeram, disamping sistem pemeliharaan dan pemberian pakan yang seadanya.

Kota Ternate merupakan salah satu daerah di Indonesia memiliki variasi ayam kampung yang tinggi dan khas, dilihat dari karakter fenotip yang ada (Soenarsih, dkk., 2018). Namun hingga sekarang ini belum ada kajian yang dapat mengidentifikasi jumlah rumpun ayam lokal asli yang beranekaragam tersebut. Disamping itu, keberadaan ragam ayam kampung sangat penting untuk sumber genetik bagi progam pemuliaan melalui penyilangan ayam di masa depan sehingga menghasilkan ras baru dengan berbagai keunggulannya sehingga dapat menunjang ketersediaan pangan khususnya pangan hewani di Kota Ternate.

Upaya pengembangan rumpun ayam lokal secara nasional, khususnya dalam upaya penyediaan bibit yang kualitas dan kuantitasnya terjamin dan berkesinambungan, maka diperlukan kajian yang komprehensif melalui progam pemuliaan rumpun ayam lokal khususnya seleksi yang terarah, dan dilanjutkan dengan sistem perkawinan yang terukur untuk dapat menghasilkan bibit ayam lokal unggul dan diterima untuk diusahakan secara komersial. Sehingga dengan demikian kami merasa penting untuk melakukan penelitian ini.

\section{MATERI DAN METODE}

\section{Tempat dan Waktu}

Penelitian ini telah dilaksanakan di Lahan Percontohan Farm Maquaponik Kecamatan Makasar Timur, Kota Ternate selama 4 (empat) bulan dengan menggunakan metode eksperimental design dengan prosedur penelitian sebagai berikut: 
Tahap awal: Penelitian dilakukan perkawinan antara ayam kampung jantan berjumlah lima ekor dengan betina berjumlah 25 ekor sebagai tetua yang berada dalam kandang individual menggunakan teknik Inseminasi Buatan (IB) sebanyak 2 kali dalam seminggu. Pengumpulan telur dilakukan satu hari setelah IB dan telur yang terkumpul diidentifikasi asal tetuanya lalu disimpan dalam ruang penyimpanan.

Tahap kedua: Hasil pengumpulan telur selama seminggu dengan jumlah sebanyak 100 butir dimasukkan ke dalam mesin penetasan. Pada hari ke-18, telur dipindahkan ke ruang hatchery berbentuk kotak-kotak berukuran $10 \times 10 \mathrm{~cm}$ dimana setiap kotak diisi telur yang berasal dari satu induk satu bapak. Setelah telur menetas dan tubuh anak ayam kampung kering diberi wing band sebagai identitas lalu dilakukan penimbangan untuk memperoleh data bobot tetas.

Tahap ketiga: Anak ayam kampung yang telah diberi wing band dimasukkan ke dalam kandang kelompok yang terbuat dari ram kawat berukuran 70 × 60 × $30 \mathrm{~cm}$ yang dilengkapi dengan induk buatan, tempat makan dan minum. Pemberian ransum dan air minum diberikan 2 kali sehari yaitu pagi dan sore hari. Penimbangan bobot hidup pada tiap individu dilakukan setiap minggu sampai dengan umur 8 minggu ini.

\section{Peubah yang diamati}

Beberapa peubah yang diukur pada penelitian ini adalah:

1. Karakter Fenotipe

1.1. Bobot Badan (diukur dengan timbangan digital $5 \mathrm{~kg}$ dengan kepekaan 0,01 kg)

1.2. Jarak antara tulang dada dengan tulang pubis (pengukaran dilakukan dengan jangka sorong kapasitas $30 \mathrm{~cm}$ dengan kepekaan 0,01 cm, diukur dari ujung os. sternum bagian belakang hingga os. pubis bagian kanan (Hapsari, 2015)

1.3. Panjang shank diukur berdasarkan tulang tarsometatarsus atau shank $(\mathrm{cm})$ diukur sepanjang tulang tarsometarsus dengan menggunakan jangka sorong.

1.4. Lingkar shank diukur berdasarkan tulang tarsometatarsus $(\mathrm{cm})$ diukur dengaan melingkari tulang tarsometarsus (shank) pada bagian tengah dengan menggunakan pita ukur yang kemudian dikonversi ke jangka sorong (Sartika, dkk., 2013; Suhardi, 2012). 
2. Produktivitas Ayam Kampung

Peubah yang diukur adalah:

2.1. Produksi, bobot dan indeks telur

2.2. Bobot badan ayam umur 2 sampai 8 Minggu

\section{Analisis Data}

Data kuantitatif yang diperoleh dianalisis secara deskriptif dengan mengikuti Indrawati, dkk (2015), yaitu sebagai berikut:

1. Nilai Maksimum dan Nilai Minimum

$$
\begin{aligned}
& \text { Rata-rata/Mean }(\mathrm{x}) \\
& \bar{x}=\frac{x_{1+x_{2}+\cdots+x_{n}}}{n} \text { atau } \bar{x}=\sum_{i-1}^{n} \frac{x_{i}}{n}
\end{aligned}
$$

2. Simpangan Baku

$$
x=\sqrt{\frac{\sum_{i-1}^{n}\left(x-\overline{x)^{2}}\right.}{n-1}}
$$

3. Koefisien Variasi

$$
K V=\frac{s}{\bar{x}} \times 100 \%
$$

\section{HASIL DAN PEMBAHASAN}

Hasil pengukuran bobot badan, jarak ujung tulang dada dengan tulang pubis, panjang dan diameter shank disajikan pada Tabel 1.

Tabel 1. Rata-rata Pengukuran Karakter Fenotip Tetua dan Koefisien Varian

\begin{tabular}{llc}
\hline Karakter Fenotip & Rataan \pm SD & KV $(\%)$ \\
\hline Bobot Badan $(\mathrm{g})$ & & \\
Jantan & $2.819 \pm 173,65(\mathrm{n}=5)$ & 6,16 \\
Induk & $1.525 \pm 151,28(\mathrm{n}=25)$ & 9,91 \\
Jarak ujung tulang dada-tulang pubis $(\mathrm{mm})$ & $41,52 \pm 4,97(\mathrm{n}=25)$ & 11,97 \\
Panjang Shank (mm) & $85,60 \pm 13,79(\mathrm{n}=25)$ & 16,11 \\
Lingkar shank (mm) & $13,20 \pm 1,29(\mathrm{n}=25)$ & 9,74 \\
\hline
\end{tabular}

Sumber: Data Olahan 2020

Tabel 1 menunjukkan bahwa bobot badan ayam jantan yang digunakan sebagai pemacek dalam penelitian ini memiliki rataan bobot badan sebesar $2.819 \mathrm{~g}$ dengan standar deviasi (SD) sebesar 173,65 dengan Kofisien Varian (KV) sebesar 6,16\% hal ini menunjukkan 
bahwa penggunaan ayam jantan sebagai pemacek memiliki bobot badan yang seragam. Hal ini sejalan degan apa yang disampaikan oleh Wardono $d k k$., (2014) bahwa populasi ayam dinyatakan seragam apabila kofisien varian tidak lebih dari 10\%. Keseragaman bobot badan ayam jantan dalam penelitian ini memang telah dilakukan seleksi terutama bobot badannya untuk mendapatkan mutu dan kualitas yang baik pada keturunannya.

Produktivitas ayam yang optimal dipengaruhi banyak faktor, salah satunya keseragaman ayam mulai dari ayam umur sehari (day old chiken) hingga masa pullet atau siap berproduksi. Keseragaman yang baik dapat diartikan ayam dalam 1 populasi memiliki kesamaan. Kondisi ini menjadi syarat penting agar performan ayam bisa mencapai nilai optimum. Seperti telah kita ketahui, tingkat produktivitas ayam petelur diperhitungkan melalui perbandingan antara jumlah produksi telur yang dihasilkan pada satu populasi tertentu. Jadi saat keseragaman ayam tidak optimal maka waktu produksi telurnya akan sangat beragam sehingga puncak produksi sulit tercapai (FAO, 2012.

Keseragaman menjadi ukuran variabilitas ayam dalam suatu populasi. Secara fisik, berat badan ayam yang digunakan haruslah seragam. Seragam disini tentulah diartikan berat badan sebagian besar ayam sama, yaitu sesuai dengan standar. Berat badan ayam dikatakan sesuai standar jika mencapai $10 \%$ dari target berat badan dari standar panduan pemeliharaan tiap strainnya. Sebagai contoh, target berat badan ayam petelur umur 12 minggu ialah 1,076 g sehingga berat badan dikatakan standar bila minimal 968 gram dan maksimal 1.184 gram (FAO, 2012)

Bobot badan ayam jantan yang digunakan dalam penelitian ini tidak berbeda jauh dengan beberapa laporan tentang bobot badan ayam lokal lainnya seperti yang dilaporkan oleh Sartika (2005) ayam nunukan jantan sebesar 2,151 g. Ulfah (2005) menyebutkan bahwa bobot badan ayam Merawang jantan berkisar antara 1,93-3,1 kg/ekor.

\section{Bobot Badan Induk}

Hasil pengukuran yang ditunjukkan pada Tabel 1, bahwa bobot badan induk yang digunakan dalam penelitian ini rata-rata adalah $1.525 \mathrm{~g}$ dengan standar deviasi sebesar 151,28, sedangkan koefisien varian (KV) sebesar 9,91 masih dalam kategori seragam karena masih dibawah angka 10 menurut wardono dkk., (2014). Sedangkan menurut Kurnianto (2010), kategori keragaman dapat dibedakan menjadi 3, yaitu keragaman kecil (KK $\leq 5 \%)$, keragaman sedang $(5 \%<\mathrm{KK}<15 \%)$ dan keragaman tinggi $(\geq 15 \%)$. Keseragaman ini menunjukkan bahwa pemilihan induk juga berdasarkan hasil seleksi pada penelitian awal 
yang telah dilakukan oleh Soenarsih dan Hoda (2018). Bobot badan induk ayam kampung yang digunakan dalam penelitian ini lebih berat dibandingkan hasil penelitian yang dilakukan Mariandayani dkk., (2013) menyatakan rataan bobot badan ayam lokal pada umur 28 minggu yaitu ayam pelung sebesar 1160,10 g $\pm 81,94$. Ayam sentul 1087,56 g $\pm 84,32$. ayam kedu 1036,10 g \pm 66,78 dan ayam kampung 1146,10 g \pm 86,12.

Keragaman pada ternak bersumber dari genetik, lingkungan dan interaksi antara genetik dan lingkungan. Untuk keragaman genetik dapat disebabka oleh gen aditif, gen dominan dan gen epistasis, sedangkan keragaman ligkungan dapat disebabkan oleh faktor cuaca, iklim, makanan, penyakit serta manajemen pemeliharaan Noor (2010).

\section{Jarak tulang dada (Os. Sternum) dengan tulang Pubis}

Jarak antara tulag dada (sternum) dengan tulang pubis dapat digunakan sebagai acuan untuk menyeleksi ayam yang berproduksi tinggi. Hasil pengukuran jarak kedua tulang pada 25 ekor induk dalam penelitian ini menunjukkan rata-rata sebesar 41,52 $\mathrm{mm} \pm 4,97$ dengan KV sebesar 11,97\% hal ini berarti ukuran jarak tulang dada dan tulang pubis memiliki keragaman yang tinggi sehingga perlu dilakukan seleksi terhadap ukuran fenotip ini.

Jarak tulang dada (Os. Sternum) dan tulang pubis ini telah dilakukan penelitian oleh Hidayat dkk., (2015) dengan kesimpulan bahwa hubungan jarak antara tulang sternum dengan tulang pubis ayam petelur strain isa brown terhadap produksi telur, indeks telur dan bobot telur secara analisis ragam tidak berbeda nyata namun terdapat korelasi yang positif antara jarak sternum dengan pubis terhadap produksi telur, indeks telur dan bobot telur dimana semakin lebar jarak sternum dengan pubis semakin tinggi produksi telur, semakin ideal indeks bentuk telur dan berat telur semakin tinggi, dan disarankan untuk peternak, apabila dalam melakukan culling atau seleksi dapat menggunakan jarak antar tulang dada (sternum) dengan tulang pubis antara 70,8-76 mm .

\section{Panjang Shank.}

Rata-rata ukuran panjang shank pada induk ayam kampung yang disajikan pada Tabel 1 adalah 85,60 dengan standar deviasi sebesar 13,79 dengan tinkat keragaman sebesar $16,11 \%$, hal ini berarti terdapat keragaman yang tinggi pada ukuran panjang shank dengan demikian perlu dilakukan seleksi yang ketat terhadap ukuran panjang shank dari flok ayam yang ada. Tingginya keragaman ini disebabkan karena pada saat pemilihan ayam induk belum melakukan seleksi pada karakter fenotip ini. 
Dibandingkan hasil penelitian ini dengan penelitian yang dilakukan oleh Subekti dan Arlina (2011) ukuran panjang shank (tulang metatarsus) relatif lebih panjang 4,53 mm, karena menurut Subekti dan Arlina bahwa panjang metatarsus ayam kampung betina dalam penelitian mereka adalah sebesar $81,07 \pm 6,77 \mathrm{~mm}$. Jika dibandingkan dengan penelitian Nishida et al. (1982) lebih pendek 0,52 mm dimana pada laporannya rata-rata panjang metatarsus sebesar $86,12 \mathrm{~mm}$.

Perbedaan hasil penelitian ini disebabkan oleh faktor genetik dan faktor lingkungan. Mansjoer (2005) melakukan penelitian di pulau Jawa, di mana ayam kampung yang ada di pulau Jawa berasal dari ayam hutan merah jawa yang dikenal dengan ayam (Gallus javanicus,) sedangkan penelitian ini dilakukan di pulau Maluku, di mana ayam kampung yang hidup di pulau Maluku berasal dari ayam hutan merah (Gallus gallus domesticus). Hal ini sesuai dengan pendapat Noor (2010) bahwa keragaman ukuran tubuh ayam Kampung dipengaruhi oleh faktor genetik dan lingkungan. Genotipe menentukan potensi karakter, sedangkan lingkungan menentukan sampai tercapai batas potensi itu. Sementara itu Arlina dan Afriani (2003) melaporkan rata-rata panjang tulang shank pada ayam kampung betina adalah $83,82 \mathrm{~mm}$, maka hasil penelitian ini lebih tinggi 1,78 mm, sedangkan Saputra (2006) mendapatkan rata-rata panjang tulang shank pada ayam kampung betina 87,70 mm, maka hasil penelitian ini lebih rendah 2,1 $\mathrm{mm}$. Perbedaan hasil penelitian ini disebabkan oleh faktor genetik dan faktor lingkungan.

\section{Lingkar Shank}

Hasil penelitian menunjukkan bahwa rata-rata ukuran lingkar shank sebesar 13,20 \pm 1,29 mm dengan $\mathrm{KV}$ sebesar 9,74\%, hal ini berarti bahwa ukuran ini tingkat keragamannya sedang menurut Kurnianto, dkk., (2010), ukuran bagian tubuh pada ayam merupakan sifat kuantitatif.

Pengukuran berbagai bagian tubuh pada ayam adalah untuk mencari korelasi dalam menduga bobot badan ternak ayam. Beberapa sifat kuantitatif yang dapat diukur yang berpengaruh terhadap produktivitas yaitu bobot badan, panjang shank dan lingkar shank. Egena et al, (2014) menyatakan, bobot badan terkait sangat positif dan dengan semua ukuran tubuh asli dari ayam. Salahi et al, (2014), menyatakan, shank dan perkembangan tulang kaki sangat berkorelasi dengan berat badan. Hal ini diperjelas oleh Jull (1978) yang menyatakan bahwa panjang kaki mempunyai korelasi positif dengan bobot badan dan menentukan komposisi tubuhnya. 
Salah satu faktor yang memengaruhi hubungan ukuran shank dengan bobot badan adalah hormon dan umur (Salahi et al., 2014). Hasil penelitian Nie et al. (2005) menunjukkan bahwa ayam yang mendapat perlakuan suntik hormon gowth-promoting akan mengalami peningkatan bobot badan sedangkan ukuran shank akan mengalami penurunan. Hasil penelitian Semakula et al., (2011) menunjukkan bahwa semakin bertambah bobot badan ayam maka ukuran panjang dan lingkar shank akan menurun. Natamijaya (2000) menyatakan, kaki ayam yang pendek menandakan produksi daging yang tinggi karena semakin pendek kaki ayam akan semakin kuat menopang tubuh.

Hasil penelitian Caglayan et al., (2011) menunjukan bahwa semakin bertambah umur ayam maka nilai korelasi antara bobot badan dengan ukuran shank akan semakin berkurang. Hal ini disebabkan karena pertumbuhan tulang ayam sudah berhenti sedangkan pertumbuhan jaringan masih terus berlanjut walaupun mulai melambat. Hasil pengukuran produktivitas ayam kampung dalam penelitian ini disajikan pada Tabel 2

Tabel 2. Produktivitas Ayam Kampung

\begin{tabular}{lcr}
\hline Produktivitas & Rataan \pm SD & KV $(\%)$ \\
\hline Produksi Telur (butir) & $9,8 \pm 1,41$ & 14,39 \\
Bobot Telur (g) & $40,24 \pm 4,89$ & 12,14 \\
Indeks Telur (\%) & $76,36 \pm 4,51$ & 5,91 \\
Bobot Tetas (g) & $28,00 \pm 3,05$ & 10,89 \\
Bobot Badan Umur 2 Minggu (g) & $102,00 \pm 13,79$ & 13,52 \\
Bobot Badan Umur 4 Minggu (g) & $211,64 \pm 21,82$ & 10,31 \\
Bobot Badan Umur 6 Minggu (g) & $313,88 \pm 37,95$ & 12,09 \\
Bobot Badan Umur 8 Minggu (g) & $507,28 \pm 62,13$ & 12,25 \\
\hline
\end{tabular}

Sumber: Data Olahan 2020

\section{Produksi Telur}

Tingkat produksi telur dari masing-masing induk sebanyak 25 ekor menghasilkan telur sebanyak 245 butir. Jumlah telur yang dihasilkan perekor induk berkisar antara 8 sampai 12 butir. Hal ini berarti produksi telur sangat beragam sesuai yang ditujukan dengan angka koefisien varian sebesar 14,39\% pada penelitian ini. Produksi terkecil jumlah 8 butir dan yang tertinggi 12 butir selama satu kali siklus produksi, sehingga rata-rata produksi adalah $10(9,8)$ butir.

Jika performan produksi ini dikaitkan dengan morfometrik ukuran jarak antara tulang dada dengan tulang pubis menunjukkan bahwa keragaman keduanya tergolong tinggi, 
sehingga seleksi perlu dilakukan terhadap ukuran jarak tulang dada dengan tulang pubis untuk mendapatkan produksi telur yang tinggi.

Ayam kampung berperan penting sebagai sumber produksi daging dan telur untuk meningkatkan kualitas gizi masyarakat, disamping sebagai sumber pendapatan tambahan. Produksi daging dan telur, produktivitas ayam lokalnya lebih rendah dibandingkan dengan produktivitas ayam ras pedaging maupun petelur. Produksi telur dapat dinyatakan dengan ukuran Henday production (HDP) dan egg mass. Henday production merupakan salah satu ukuran produktivitas.

Menurut Salahi et al., (2014) ayam kampung dengan pemeliharaan secara tradisional hanya menghasilkan produksi telur 58 butir/ekor/tahun. Lebih lanjut dikemukakan bahwa ayam kampung yang mengasuh anaknya sampai lepas sapih, produksi telur hanya mencapai 52 butir/ekor/ tahun, tapi bila dipisahkan anaknya sejak menetas dapat mencapai 115 butir/ekor/tahun. Pemeliharaan secara tradisional bobot badan 1450,63 g sampai umur 8 bulan dengan produksi telur 60 butir, sedangkan dengan pemeliharaan secara intensif bobot badan mencapai 1674,96 g dengan produksi telur 105 butir.

\section{Bobot Telur}

Bobot telur secara keseluruhan mencapai 1005,9 g dari 245 butir yang dihasilkan oleh 25 ekor induk dengan nilai rataan sebesar 40,26 g. Bobot tertinggi adalah 49,9 g dan yang terendah seberat $34 \mathrm{~g}$ sehingga koefisien varian sebesar 12,14\%. Hal ini menunjukkan bahwa bobot telur yang dihasilkan tingkat keragamannya masih tergolong tinggi. Tingginya bobot telur disebabkan karena pada saat pemilihan telur tidak dilakukan seleksi, oleh sebab itu seleksi perlu dilakukan untuk mendapatkan bobot telur yang tinggi dan seragam karena menurut Egena et al., (2014) bahwa bobot telur dipengaruhi oleh ukuran tubuh induk ayam. Induk ayam yang besar menghasilkan telur yang besar, dari telur yang besar akan dihasilkan anak ayam dengan pertumbuhan yang cepat. Setiap kenaikan satu gam bobot telur tetas meningkatkan 5 gam bobot badan ayam pedaging pada umur 9 minggu.

Hasil yang diperoleh pada penelitian ini, jika dibandingkan dengan laporan penelitian sebelumnya menunjukkan bahwa rata-rata bobot telur pada penelitian ini perbedaannya tidak terlalu signifikan dengan penelitian-penelitian sebelumnya seperti yang dilaporkan oleh Wardono (2014) dan Septiwan (2007) masing-masing menghasilkan bobot telur 42,49\% dan $42,47 \%$. 


\section{Indeks Telur}

Berdasarkan asal hewannya bentuk telur bermacam-macam mulai dari hampir bulat dan lonjong, beberapa faktor dari kondisi induk penghasil telur dapat mempengaruhi bentuk telur, contohnya faktor turun-temurun, umur induk ketika bertelur serta sifat fisiologis didalam tubuh induk. Ukuran bentuk telur biasa dinyatakan dengan indeks perbandingan antara lebar dan panjang dikalikan 100. Adapun panjang telur ayam kampung yang idealnya adalah kurang lebih $5 \mathrm{~cm}$, sedangkan lebar telur ayam kampung adalah $4 \mathrm{~cm}$ (Suprijatna dkk., 2008).

Hasil penelitian menunjukkan bahwa rata-rata indeks telur adalah 76,36 \pm 4,51\% dengan KV sebesar 5,91 dengan demikian telur-telur yang diperoleh dari penelitian ini seragam dengan kisaran rata-rata untuk panjang 49,64 mm dan lebar 37,94 mm. Indeks telur ini dalam kategori baik. Sementara itu menurut Sodak (2011) kisaran indeks telur yang normal adalah 70\%-76\%.Telur yang baik berbentuk oval dan idealnya mempunyai "Shape Index" (SI) antara 72-76.

Nutrisi yang terserap oleh tubuh ayam yang digunakan sebagai sumber energi untuk pemenuhan hidup pokok sehingga energi yang digunakan untuk organ reproduksi dan produksi belum optimal. Bentuk telur yang tidak proporsional berupa bentuk telur yang tidak bulat, terdapat bentuk cetak tubuh pada telur (body-check) dan tidak seimbang perbandingan panjang dan lebarnya. Hal ini disebabkan oleh daya kerja alat reproduksi ayam. Penurunan kemampuan daya cerna pakan, ketersediaan Ca dan mineral lainnya pada tubuh ayam, dan kemampuan alat reproduksi yang terjadi akan berpengaruh terhadap kualitas telur yang dihasilkan (Sodak, 2011).

Bobot tubuh ayam juga mempengaruhi bentuk telur, bobot tubuh ayam yang semakin besar memungkinkan ukuran isthmus semakin besar dan lebar, sehingga bentuk telur yang dihasilkan akan cenderung bulat. Bentuk telur yang semakin bulat tersebut umumnya memiliki nilai indeks telur yang lebih tinggi (Sodak, 2011).

Pengaruh perubahan suhu dan kelembapan lingkungan yang secara mendadak secara langsung dapat menyebabkan stress pada ayam. Ketika ayam mengalami stress, produksi Follicel Stimulating Hormone (FSH) akan terganggu yang diduga berdampak negatif pada kerabang telur yang dihasilkan. Hormon FSH mempengaruhi sekresi steroid yaitu estrogen dan progesteron., yang dihasilkan oleh sel theca dan sel ganulosa, yang penting untuk pembentukan kuning telur, albumin dan cangkang telur. 


\section{Bobot Tetas}

Menurut Hasan (2005), bobot tetas berkorelasi positif dengan bobot telur tetas. Semakin besar bobot telur maka semakin besar pula bobot tetas yang dihasilkan. Hasil penelitian menunjukkan bahwa rata-rata bobot tetas 28,00 $\pm 3,05$ dengan tingkat keragaman sebesar 10,89. Begitu halnya dengan penelitian yang dilakukan oleh Sadid dkk, (2016) meghasilkan rata-rata bobot tetas sebesar 34,17 g. Beberapa laporan penelitian yang terkait dengan bobot tetas ayam lokal seperti ayam Kedu hitam rata-rata 28,98 g (Nataamijaya, 2008), pada ayam Kedu putih 25,5 g, pada ayam Sentul sebesar 32,2 g (Hidayat dan Sopiyana 2010), dan pada ayam Pelung 31,83 g (Darwati, 2000).

Perbedaan yang nyata ini diduga disebabkan oleh perbedaan jumlah kuning telur dan putih telur sebagai sumber nutrisi selama perkembangan embrio. Bobot telur tinggi mengandung jumlah kuning telur dan putih telur tinggi. Semakin banyak kuning telur dan putih telur maka ketersediaan nutrisi untuk perkembangan embrio semakin banyak, sehingga bobot tetas yang dihasilkan akan lebih besar. Hal ini selaras dengan pendapat Sudaryanti (1985) bahwa bobot telur memberikan perbedaan pertumbuhan embrio, baik dalam jumlah sel maupun ukuran selnya. Salmanzadeh et al. (2016) melaporkan bahwa lambatnya perkembangan embrio tergantung proses glukoneogenesis dari asam amino, yang dapat mengakibatkan penurunan protein otot dan menurunkan berat tetas.

\section{Bobot Badan Umur 2 - 8 Minggu}

Pada Tabel 2 menunjukan bahwa rata-rata bobot badan ayam kampung pada umur 2 sampai 8 minggu memiliki koefisien keragaman pada kisaran $10,31 \%$ pada bobot badan umur 4 Minggu dan 13,52 \% keragaman tinggi pada bobot badan umur 2 Minggu. Rata-rata bobot badan umur 2 minggu adalah 102,00 $\pm 13,79$ g. Hasil ini lebih rendah dari penelitian yang dilakukan oleh Lukmanuddin dkk. (2018) yang melaporkan bobot badan pada umur

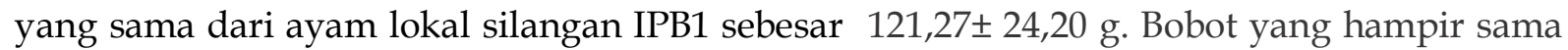
jika dibandingkan dengan hasil penelitian yang dilakukan oleh Urfa dkk. (2017) yang melaporkan bobot badan ayam Kampung Unggul Balitnak yaitu sebesar 102,8 g. Namun jika dibandingkan dengan penelitian yang dilakukan oleh Iskandar, (2019) khusus untuk bobot badan umur 4 minggu lebih tinggi $47 \mathrm{~g}$ untuk penelitian ini. Sedangkan untuk umur 8 minggu lebih rendah 45,7 g. Adapun hasil penelitian Creswell dan Gunawan yang dikutip Iskandar (2019) disajikan pada Tabel 4 
Tebel 4. Pertumbuhan beberapa Ayam Lokal dalam Pemeliharaan Intensif

\begin{tabular}{lcllll}
\hline Peubah & Kampung & $\begin{array}{l}\text { Kedu } \\
\text { Hitam }\end{array}$ & $\begin{array}{l}\text { Kedu } \\
\text { Putih }\end{array}$ & Nunukan & Pelung \\
\hline \multicolumn{5}{c}{ Bobot hidup g/ekor } \\
\hline 1 Hari & 26,2 & 27,2 & 25,5 & 30,2 & 29,6 \\
4 Minggu & 164 & 168 & 146 & 160 & 174 \\
8 Minggu & 553 & 602 & 550 & 482 & 589 \\
12 Minggu & 872 & 831 & 857 & 754 & 917 \\
\hline
\end{tabular}

Sumber: Iskandar (2019)

\section{KESIMPULAN}

Hasil penelitian menunjukkan bahwa tingkat keragaman baik karakter fenotip maupun tingkat produktivitas ayam buras masih dalam kategori tinggi, maka upaya seleksi perlu dilakukan secara kontinyu untuk memperoleh strain ayam buras murni.

\section{DAFTAR PUSTAKA}

Arlina, F., dan Afriani,T. 2003. Karakteristik genetik eksternal dan morfologi ayam kampung. Jurnal Peternakan dan Lingkungan, 9(2), 1-5.

BISE. 2010. Genetic resources. Copenhagen (Denmark): Biodiversity Information System for Europe.

Caglayan, T., Kirikci, A. Gunlu, and Alasahan, S. 2011. Some body measurements and their correlations with live weight in the rock partridge (Alectoris gaeca). African Journal of Agicultural Research, 6(7), 1857-1861.

Darwati, S. 2000. Produktivitas ayam kampung, pelung dan resiprokalnya. Media Peternakan, 23(2), 32-35.

Egena, S.S.A., Ijaiya, A.T., Ogah, D.M. and Aya, V.E .2014. Principal component analysis of body measurements in a population of indigenous Nigerian chickens raised under extensive management system. Slovak Journal of Animal Science, 47(2), 77-82.

FAO. 2012. Cryoconservation of Animal Genetic Resources. Rome (Italy): FAO.

Hapsari, IP. 2015. Ukuran tubuh dan produksi telur ayam hasil persilangan ayam lokal dengan ayam ras pedaging. Skripsi. Institut Pertanian Bogor, Bogor.

Hasan, S. M. 2005. Physiology, endocrinology, and reproduction: egg storage period and weight effect on hatchability. Poultry Science, 84(12) 1908-1912.

Hidayat, C., Iskandar, S. dan Sumiati. 2015. Persentase bobot karkas dan potongan komersial ayam Sentul-G3 yang diberi ransum mengandung dedak tinggi dengan suplementasi fitase dan ZnO. Jurnal Ilmu Pertanian Indonesia, 20(2), 131-140.

Hidayat, C. dan Sopiyana S. 2010. Potensi Ayam Sentul sebagai Plasma Nutfah Asli Ciamis Jawa Barat. Balai Penelitian Ternak, Bogor

Hiemstra, SJ., Lende, TVD., Woelders H. 2011. The potential of cryopreservation and reproductive technologies for animal genetic resources conservation strategies. Cryobiology. Food and Agriculture Organization of the United Nations (FAO), 63:2535. 
Indrawati, E., Saili, T., dan Rahadi, S., 2015. Fertilitas, daya hidup embrio, daya tetas dan bobot tetas telur ayam ras hasil inseminasi buatan dengan ayam tolaki. Jurnal Ilmu dan Teknologi Peternakan Tropis, 2(2), 10-18.

Iskandar, S. 2019. Strategi pengembangan ayam lokal. Wartazoa, 16(4), 190-197.

Jatmiko. 2001. Studi fenotipe ayam pelung untuk seleksi tipe ayam penyanyi. Tesis. Progam Pascasarjana.Institut Pertanian Bogor.

Jull, M. A. 1978. Poultry Husbandry $3^{\text {rd }}$ Ed. Mc. Graw-Hill Publishing Co. Ltd. New Delhi.

Kurnianto, E., Johari, S. dan Fadliyah, Y. 2010. Penampilan dan nilai heritabilitas beberapa sifat kuantitatif pada ayam kedu. Agromedia, 28(1), 54-59.

Lukmanuddin, M., Sumantri, C. dan Darwati, S. 2018. Ukuran tubuh ayam lokal silangan IPB-D1 generasi ke lima u,ur 2 samapi 12 minggu. Jurnal Ilmu Produksi dan Teknologi Hasil Peternakan, 6(3), 113-120.

Mansjoer, S. S., 2005. Studi sifat-sifat ekonomis yang menurun pada ayam kampung. Laporan Penelitian No. 15/Penelitian/PUT/IPB/1979-1980. Bogor (ID): Fakultas Peternakan IPB.

Nataamijaya, A. G. 2000. The native chicken of Indonesia. Bulletin Plasma Nutfah, 6(1),1-6.

Nataamijaya, A. G. 2008. Karakteristik dan produktivitas ayam kedu hitam. Buletin Plasma Nutfah 14(2), 85-89.

Nie, Q., Sun, B., Zhang, D., Luo, C., Ishag, N.A., Lei, M., Yang, G. and Zhang, X. 2005. High diversity of the chicken gowth hormone gene and effects on gowth and carcass traits. Journal of Heredity, 96(6), 698-703.

Nishida, T., Nozawa., K., Hayasi, Y., Hashiguchi, T. and Mansjoer, S.S. 1982. Body measurement and analis on exsternal genetic characters of Indonesian native fowl. The Origin and Phylogeny of Indonesian Native Livestock. Res Gr Overseas Sci Surv Rep. 3:73-83.

Noor, R. 2010. Genetika Ternak. Penebar Swadaya, Jakarta.

Risnajati, D. 2012. Perbandingan bobot akhir,bobot karkas, dan persentase karkas berbagai strain broiler. Sains Peternakan, 10(1), 11-14.

Salahi, A., Khabisi, M.M. and Anissian, A. 2014. Effects of infectious bursal disease (IBD) on shank length and diameter, body weight and mortality in broiler breeder at rearing period. Turkish Journal of Veterinary and Animal Sciences, 38(1), 34-39.

Salmanzadeh, M., Ebrahimnezhad, Y., Shahryar, H. A., and Be-heshti, R. 2016. The effects ofin ovoinjection of glucose and mag-nesium in broiler breeder eggs on hatching traits, performance,carcass characteristics and blood parameters of broiler chickens. Arch. Geflügelk., 76(4), 277-284,

Saputra, H. 2006. Penampilan kuantitatif ayam kampung pada pemeliharaan ekstensif di Kecamatan Kuranji Kota Padang. Pros. Seminar Peternakan, USU Medan.

Sartika, T. 2012. Peningkatan mutu bibit ayam kampung melalui seleksi dan penggunaan penanda genetik promotor prolaktin dalam MAS (Marker Assisted Selection) untuk mempercepat seleksi. Ringkasan Disertasi. Sekolah Pasca Sarjana, Institut Pertanian Bogor, Bogor.

Sartika, T. 2013. Perbandingan morfometrik ukuran tubuh Ayam KUB dan Sentul melalui pendekatan analisis diskriminan. Seminar Nasional Teknologi Peternakan dan Veteriner. Medan, 3-4 september 2013. Puslitbang Peternakan, Medan. 561-570.

Semakula J., Lusembo, P., Kugonza, D.R., Mutetikka, D., Ssennyonjo, J. and Mwesigwa, M. 2011. Estimation of live body weight using Zoometrical Measurements for improved marketing of indigenous chicken in the lake victoria basin of Uganda. Livestock Research for Rural Development, 23(8). 
Septiwan, R. 2007. Respons Produktivitas dan Reproduktivitas Ayam Kampung dengan Umur Induk yang Berbeda. Skripsi. Fakultas Peternakan Institut Pertanian Bogor, Bogor

Sodak, F.J. 2011. Karakteristik fisik dan kimia telur ayam arab pada dua peternakan di Kabupaten Tulung Agung, Jawa Timur. Departemen Ilmu Produksi dan Teknologi Peternakan. Fakultas Peternakan. Institut Pertanian Bogor.

Soenarsih, S., dan Hoda, A. 2018. Pengetahuan kokal masyarakat tentang produktivitas dan keragaman fenotipe Ayam (Gallusgallus domesticus) sebagai upaya menunjang ketahanan pangan masyarakat Kota Ternate https://www.researchgate.net/publication

Sudaryani, T., 1985. Kualitas telur. Penebar Swadaya, Jakarta.

Suhardi, 2012. Identifikasi karakteristik morfologi ayam lokal khas dayak dari Kabupaten Berau, Kalimantan Timur. Jurnal Teknologi Pertanian, 7(2), 81-86.

Suprijatna, E., Atmomarsono, U. dan Kartasujana, R. 2008. Ilmu Dasar Ternak Unggas. Cetakan ke-2. Penebar Swadaya, Jakarta.

Urfa, S., H. Indrijani., W. Tanwiriah. 2017. Model kurva pertumbuhan ayam kampung unggul balitnak (KUB) Umur 0-12 Minggu. Jurnal Ilmu Ternak, 17(1), 59-66.

Wardono, P., Sugihono, C., Kusnadi dan Suprijono. 2014. Prosiding Semnas. Inovasi teknologi pertanian spesifik lokasi. P-577. Banjarbaru. 